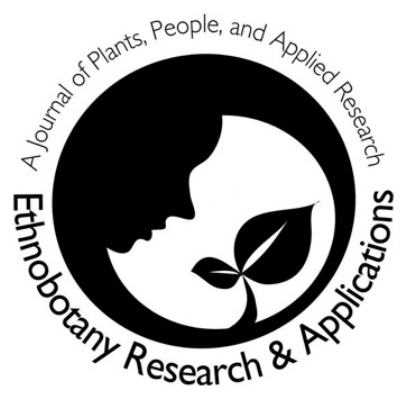

\title{
Gendered plants and plant categorization by gender: classificatory and "storied" knowledge in Trás-os-Montes, Portugal
}

\author{
Amélia Frazão-Moreira and Ana Maria Carvalho
}

\section{Research}

\begin{abstract}
Background: An anthropomorphizing process arises out of classification systems, whereby analogy is drawn between the social differences of gender and the morphological and biological characteristics used to designate or classify plants. On the other side, it is observed that men and women categorize plants differently on the basis of their practices and knowledge.

This paper addresses two assumptions: the consistent cognitive mechanisms of attributing gender to plants in classifications and the local differentiation of knowledge and social variability of categorization of plants based on gender.
\end{abstract}

Methods: The data presented results from research carried out in Portugal in two rural villages, using participant observation, structured ethnobotanical interviews and free pile sorting task (79 interlocutors; among them 11 local experts). A literature review provided some examples from studies conducted in other contexts, which have been used to analyze and discuss our findings.

Results: Gender differentiations are present in plants naming and identification. Plants morphologically similar can take different designations or have the same name with gender variations depending on people's perceptions of female or male features. The survey conducted in these Portuguese case studies shows also a gender variability of knowledge, although knowledge about plants is usually quite shared.

Conclusions: The mechanism of plant differentiation using gender attributes seems to be transcultural. However, the plant classification by gender must be explained from a local standpoint and knowledge about plants should be understood as a "storied knowledge".

Key words: plant nomenclature, ethnobotanical classification, gender, storied knowledge

Correspondence
Amélia Frazão-Moreira' and Ana Maria Carvalho²
${ }^{1}$ CRIA (Centre for Research in Anthropology) /
NOVA FCSH (NOVA School of Social Sciences and
Humanities), Av. de Berna, 26 C, 1069-061 Lisboa,
Portugal (e-mail: amoreira@fcsh.unl.pt)
${ }^{2}$ Centro de Investigação de Montanha (CIMO), ESA,
Instituto Politécnico de Bragança, Campus de Santa
Apolónia, 5300-253 Bragança, Portugal (e-mail:
anacarv@ipb.pt)
*Corresponding Author: amoreira@fcsh.unl.pt
Ethnobotany Research \& Applications
21:44 (2021)

\section{Background}

The cultural processes in which plant and nonhuman animal worlds are distributed in an objective and consistent manner into socially recognized and shared cognitive categories are described by several authors as the construction of ethnobiological classifications (e.g. Atran 1986, Berlin et al.1973, Berlin 1992, Ellen 1979, 1993). Classifications require different skills and tasks such as naming, recognizing, identifying, and organizing plants and animals into reference systems that include systematic categories. The local names of plants and animals, as well as the human relations with them expressed by classification categories, provide significant information on the diversity of natural 
resources existing in a given environment. How people structure a set of ideas about other living beings shows the significance attributed to different species, among them endangered species. Thus, the study of folk classifications goes beyond cognitive research because it is also a valuable tool to understand biodiversity and promote sustainable management of natural resources, species, habitats, as well as to support conservation strategies of biocultural heritage (Cardoso et al. 2012, Carvalho \& Frazão-Moreira 2011, González et al. 2017, Jinxiu et al. 2004).

Berlin et al. (1973) argued that the systems of ethnoclassification are based on a universal taxonomic structure. According to the model, developed by Berlin (1978, 1992), folk classifications emerging from different societies are arranged in a hierarchical taxonomic structure that consists of five mutually exclusive levels or ranks. Taxa from each level show similar taxonomical, linguistic and biological characteristics. Classifications are made up of hierarchically arranged categories according to the principles of disjunction or inclusion. These categories are separated with no intersecting areas and are included in a more general level. Such approach has been the focus of important debate. Several objections consider that the model used tends to present ethnobiological classifications in a reductionist manner because it only reflects the definition of morphological or linguistic categories (Martin 1975, Morris 1984); even more arguments assume the existence of a hierarchical model based on a binary logic (e.g. Friedberg 1970, 1986, Newmaster et al. 2006). On the other hand, the above-mentioned model, focused on formal structures of classification, does not take into account social variability, as plant and animal classifications are conceived and managed in different ways by different social actors and according to specific circumstances (e.g. Ellen 1979, 2006, Frazão-Moreira 2001, 2009, Sillitoe 2002, Tamisari \& Bradley 2005).

Ingold (2000, 2011) points out that human beings do not apply in their practices a configuration of structural mental representations (for instance classifications), but rather that knowledge implies their continuous involvement, in perception and action, with the environment components. That is, "far from being copied, ready-made, into the mind in advance of its encounter with the world, knowledge is perpetually 'under construction' within the field of relations established through the immersion of the actor-perceiver in a certain environmental context. Knowledge, in this view, is not transmitted as a complex structure but is the ever-emergent product of a complex process. It is not so much replicated as reproduced" (2011:159). In this sense, knowledge is not classificatory but rather "storied".

These theoretical frameworks, at first sight contradictories, are the basis for our main research goals:

(i) To know whether gender is an operator in classification, as it is morphology, habitat, origin or use, and to examine its role as a mechanism of ethnobiological classification and especially in naming (Garnier 1987, Newmaster et al. 2006).

(ii) To find if there is social gender variability in the categorization of plants, namely if men and women use different knowledge when they group plants, within the same social framework and cultural context.

As Howard (2003a: 26) highlighted "(...) it appears that little ethnobotanical research, particularly that which deals with cognition and folk-taxonomic systems, addresses the question of how the gendered nature of language influences the ways people name and classify plants, and, in turn, how this might reflect gender power relations."

Although we are aware that gender classifications are part of a complex system of naming, distinguishing and categorizing that involves other criteria (such as morphology, habitat, utility, beliefs, among others), this study intends to contribute to fill the gap mentioned by Howard (2003a); thus, to increase the visibility of gender issues within cognitive processes.

Evidence of different knowledge between women and men provides arguments to deconstruct the idea that rural societies are homogenous. It also raises awareness of the important role of women in the maintenance of local ecological knowledge, complementing studies carried out in Portugal (Carvalho 2016, Carvalho \& Morales 2013) and other places (e.g. Kujawska et al. 2017, Price 2006, Torres-Avilez et al. 2016, Voeks 2007). Female and male knowledge is related to their activities. For instance, knowledge of food uses, and some specific medicinal uses of wild plants are very often a result of female experiences transmitted among women, highlighting a gender distribution of social memory. The role of women and their agroecological expertise must not be neglected either in terms of safeguarding the intangible cultural heritage concerning nature, or as key agents for biodiversity conservation and management (Camou-Guerrero 2007, Howard 2003b, Iriate et al. 2000, Pfeiffer \& Butz 2005). 
In addition, our general assumption is that the attribution of a gender to plants, through differentiating between female and male plants in naming or distinguishing procedures, is an important cognitive operation. Moreover, we have found a social variability, specifically with the difference in the way women and men classify plants based on gendered knowledge, that is to say, plants knowledge is locally "storied".

\section{Materials and Methods Data collection}

A study conducted in two rural villages from Trás-osMontes (TM), Northeastern Portugal (Quintanilha and Póvoa small villages) provided useful information to explore the presence of male and female representations in three components of plant classification: naming (ethnobotanical nomenclature or terminology), identification and differentiation (recognition of the physical discontinuities among plants and setting up different categories), and classification (sorting, organizing species into comprehensive categories).

A literature review was carried out in order to provide an overview of relevant findings and debates on the topic that could contributed to analyze and discuss our results.

Therefore, the comparison of our data with other study cases was not neglected as an attempt has been made to present examples of gender classification from studies within different geographic scenarios; however, it was not our intention to make a comprehensive review of all the ethnobotanical studies in which gender attributes are presented in vernacular names of plants. Moreover, our search of literature did not provide extensive information on the topic because, as mentioned before, there is a lack of research on gendered knowledge. Thus, we have also used findings from ethnobotanical studies on subjects other than classification.

The selected examples from the literature reviewed considered emic explanations and cultural reasons to attribute names to the plants described. The analysis and comparison of some data from other surveys highlight interesting aspects of plant categorization and local nomenclature in line with our first objective, supporting the hypothesis that gender is a universal metaphorical operator in plant classification.

In every example presented, the scientific botanical identification is provided and, sometimes, there is a coincidence between the local classification and the formal taxonomy. Nonetheless, such coincidence never addresses a strict scientific perspective to validate or verify the truthfulness of local classifications. The comparison between ethnoclassifications and modern scientific classifications is fruitful in many ways. This approach enables the dialogue between scientists and local partners, which is particularly crucial in applied research (e.g. Sillitoe 2006); moreover local knowledge about species diversity manifested in ethnoclassifications can provided evidence for science itself (e.g. botany, ecology, resources conservation and others) (Pfeiffer \& Uril 2003, Ragupathy et al. 2009). However, an exhaustive comparison between emic and scientific classifications would have gone beyond the objective of this study.

Furthermore, the fieldwork conducted led us to meet our second objective: to understand how social differences of gender emerge from plant categorization processes and to find out "storied" knowledge.

Ethnographic methodology (participant observation) and structured ethnobotanical interviews (Alexiades 1996, Bernard 2002, Madden 2010) were carried out in TM small villages of Quintanilha and Póvoa with inhabitants' agreement and according to the ethical guidelines of the International Society of Ethnobiology (2006). On behalf of a broader project (Frazão-Moreira \& Carvalho 2009), we firstly identified several key-interlocutors, using purposive sampling techniques (Bernard 2002), who introduced us to the local context of plant use. Our key-interlocutors are local experts, people who have a consensual reputation as particularly knowledgeable about natural resources and local culture. They provided important information about flora and helped with the recognition of different locally meaningful plant use categories (food, medicinal, fodder, fuel, handicraft, ritual and ornamental). Then we conducted ethnobotanical interviews and pile sorting tasks (Bernard 2002, Martin 1995) with 79 interlocutors (42 in Quintanilha and 37 in Póvoa), selected by stratified random sampling (Alexiades 1995, Bernard 2002) and corresponding to men and women of different ages (from 10 to 89 years old), school experiences and personal careers.

This paper only discusses results based on ethnographic methods applied to people over the age of 40: 25 men and 26 women. As it happens in many rural societies (Heckler 2002, Ross 2002; Somnasang \& Moreno-Black 2000, Zent 2000) we found a great erosion of traditional ecological knowledge, because the younger interlocutors assumed that they knew little about plants (FrazãoMoreira et al. 2007; 2009), which unable to work with all the population strata of the studied communities. 
Moreover, in this survey, the pile sorting method was not selected to search for "hidden cognitive structures", but rather because this method involves the accomplishment of practical tasks, which provides a deeper approach to knowledge than questionnaires, making possible to obtain comparative results in a more systematic way than through participant observation.

Taking advantage of participant observation and informal interviews with local experts, previously conducted in the communities, and based on an ethnobotanical reference collection, we chose 11 different plants to perform the pile sorting tasks, guided by local experts' consensus and expertise. Such selected species should have a wide meaning at a local social level and satisfy the following assumptions:

1) species easily associated with different common uses and potentially belonging to the main use categories locally recognized (food, medicinal, fodder, fuel, handicraft, ritual and ornamental); 2) plants having different life forms (trees, shrubs and herbs); 3) and different growing places (e.g., woodland, scrubland, homegarden).

We started our survey in Quintanilha and then proceed to the second village, Póvoa. Because the surveyed villages correspond to different edaphic conditions (briefly summarized in study sites section), which affect plant cover and crops, the list of selected plants had to be adjusted in the case of Póvoa, so that other similar species (e.g. emblematic plants, matching the main bio-ecological features and use categories defined) were chosen considering their availability in Póvoa. Thus, whenever the same species occurred in both villages it was always selected. If a previous selected species was missing in Póvoa, it was replaced, according to local experts' knowledge, by another species with comparable characteristics (e.g., life form, main use) and, if possible, from the same scientific botanical family.

For instance, in Quintanilha, we chose cheirosinha (a thyme species, Thymus zygis L.) as representative of medicinal and condiment categories; since this species was not available in Póvoa it was replaced by another tomilho-branco (mastic thyme, Thymus mastichina L.) which has the same uses, belongs to the same genus and it is included in the same botanical family. Table 1 shows the set of selected plants.

At the beginning of every interview, each interlocutor was asked to name the plants and to describe what they knew about each one. We then asked them to do a free pile sorting task whereby the plants were organized according to categorization criteria of their own choice. Although we have selected the plants bearing in mind use-reports of previous fieldwork in the surveyed area, each interviewee was free to make their own options.

Table 1. Plants used for the interviews in both study cases (Quintanilha and Póvoa, TM, Portugal). Selected meaningful plants to each study area and use-category

\begin{tabular}{|c|c|c|c|}
\hline \multicolumn{2}{|l|}{ Quintanilha } & \multicolumn{2}{|l|}{ Póvoa } \\
\hline $\begin{array}{l}\text { Local name (English name) } \\
\text { Scientific name }\end{array}$ & $\begin{array}{l}\text { Main local } \\
\text { uses reported }\end{array}$ & $\begin{array}{l}\text { Local name (English name) } \\
\text { Scientific name }\end{array}$ & $\begin{array}{l}\text { Main local uses } \\
\text { reported }\end{array}$ \\
\hline $\begin{array}{l}\text { arçã or arcenha (Spanish } \\
\text { lavender) } \\
\text { Lavandula stoechas L. }\end{array}$ & $\begin{array}{l}\text { medicinal } \\
\text { condiment } \\
\text { fodder }\end{array}$ & $\begin{array}{l}\text { romeiro or arçã (Spanish lavender) } \\
\text { Lavandula stoechas L. }\end{array}$ & $\begin{array}{l}\text { medicinal } \\
\text { condiment } \\
\text { fodder }\end{array}$ \\
\hline $\begin{array}{l}\text { agrião (watercress) } \\
\text { Rorippa nasturtium-aquaticum } \\
\text { (L.) Hayek. }\end{array}$ & food & $\begin{array}{l}\text { norça (bryony) } \\
\text { Bryonia dioica Jacq. }\end{array}$ & food \\
\hline $\begin{array}{l}\text { agrião-real (annual valerian) } \\
\text { Centranthus calcitrapae (L.) } \\
\text { Dufr. }\end{array}$ & $\begin{array}{l}\text { medicinal } \\
\text { food }\end{array}$ & $\begin{array}{l}\text { mangerico-do-monte (oregano) } \\
\text { Origanum virens Hoffmanns. et } \\
\text { Link. }\end{array}$ & $\begin{array}{l}\text { medicinal } \\
\text { condiment }\end{array}$ \\
\hline $\begin{array}{l}\text { ruda or arruda (fringed rue) } \\
\text { Ruta chalepensis L. }\end{array}$ & ritual & $\begin{array}{l}\text { ruda or arruda (fringed rue) } \\
\text { Ruta chalepensis L. }\end{array}$ & ritual \\
\hline $\begin{array}{l}\text { carqueja (broom-like Iberian } \\
\text { fabaceae) } \\
\text { Genista tridentata L. }\end{array}$ & $\begin{array}{l}\text { fuel } \\
\text { medicinal } \\
\text { condiment } \\
\text { fodder }\end{array}$ & $\begin{array}{l}\text { escova-amarela (common broom) } \\
\text { Cytisus scoparius (L.) Link }\end{array}$ & $\begin{array}{l}\text { fuel } \\
\text { medicinal } \\
\text { handicraft } \\
\text { fodder }\end{array}$ \\
\hline $\begin{array}{l}\text { carrasco, azinheira (holm oak) } \\
\text { Quercus rotundifolia Lam. }\end{array}$ & $\begin{array}{l}\text { fodder } \\
\text { medicinal } \\
\text { fuel } \\
\text { handicraft }\end{array}$ & $\begin{array}{l}\text { freixo (narrow-leafed ash) } \\
\text { Fraxinus angustifolia Vahl }\end{array}$ & $\begin{array}{l}\text { fodder } \\
\text { medicinal } \\
\text { fuel } \\
\text { handicraft }\end{array}$ \\
\hline cheirosinha (Thymus sp.) & medicinal & tomilho-branco (mastic thyme) & medicinal \\
\hline
\end{tabular}




\begin{tabular}{|c|c|c|c|}
\hline Thymus zygis L. & condiment & Thymus mastichina L. & condiment \\
\hline $\begin{array}{l}\text { espinheiro (common hawthorn) } \\
\text { Crataegus monogyna Jacq. }\end{array}$ & $\begin{array}{l}\text { ornamental } \\
\text { medicinal }\end{array}$ & $\begin{array}{l}\text { espinheiro (common hawthorn) } \\
\text { Crataegus monogyna Jacq. }\end{array}$ & $\begin{array}{l}\text { ornamental } \\
\text { medicinal }\end{array}$ \\
\hline $\begin{array}{l}\text { erva-prata or prata (nailwort) } \\
\text { Paronychia argentea Lam. }\end{array}$ & medicinal & $\begin{array}{l}\text { ervas-lobas (like spotted rockrose) } \\
\text { Tuberaria lignosa (Sweet) Samp. }\end{array}$ & medicinal \\
\hline $\begin{array}{l}\text { fiolho (fennel) } \\
\text { Foeniculum vulgare Mill. }\end{array}$ & $\begin{array}{l}\text { medicinal } \\
\text { condiment }\end{array}$ & $\begin{array}{l}\text { fiolho (fennel) } \\
\text { Foeniculum vulgare Mill. }\end{array}$ & $\begin{array}{l}\text { medicinal } \\
\text { condiment }\end{array}$ \\
\hline $\begin{array}{l}\text { tremoceiro bravo (blue lupine) } \\
\text { Lupinus angustifolius } \mathrm{L} \text {. }\end{array}$ & no defined use & $\begin{array}{l}\text { grama (stonecrop sp.) } \\
\text { Sedum sp. }\end{array}$ & no defined use \\
\hline
\end{tabular}

\section{Study sites}

The focus of this paper emerged from our research conducted in two Portuguese rural villages (Quintanilha in Bragança district and Póvoa in Miranda do Douro district) in Trás-os-Montes (TM) region, Northeastern Portugal (Figure 1).

Both study sites are inside two main protected areas in the most northeastern part of the country, on the border with Spain: Quintanilha is in Montesinho Natural Park (PNM) and Póvoa in Douro International Natural Park (PNDI). Besides a long history of human occupation and rural livelihood these two territories still present a great diversity of natural and semi-natural habitats (e.g. deciduous woodlands, riparian lands, grasslands managed for grazing or cutting, among others) and humanized landscapes, which are important reservoirs of natural resources and cultural heritage. Many small villages are scattered all over assorted multifunctional landscapes (agricultural and forest interacting patches), mostly influenced by historical and biogeographical events, harsh climatic and soil conditions. Such natural environment has shaped daily activities (e.g. pastoralism, extensive agriculture and forestry) of the human communities, which were predominantly rural until recently
(Carvalho \& Frazão-Moreira 2011, Gonzalez et al. 2017).

The PNM is a mountainous area combining Continental and Mediterranean climate features, which promote forests dominated by deciduous trees, mainly oaks and riparian species (e.g. ashes, willows, maples and cherries), bushy evergreen shrubs (e.g. from heather and broom botanical families) and grasslands with typical associated herbaceous vegetation (ICNF 2020). The PNDI is a plateau nearby the monumental canyons of the international river Douro. The northern zone of PNDI natural park presents climatic characteristics and plant communities similar to those of the PNM. However, the eastern and southern parts have Mediterranean climate type and the influence of several microclimates with little precipitation and mild winter temperatures. The resulting vegetation has distinctive diversity of biotopes, ranging from a variety of regional to Iberian endemisms. Evergreen forests, mostly of junipers, holm oaks and cork oaks, mixed forests (including the Portuguese oak, a species native to the western Mediterranean region), scrublands, sunstroke species (heliophytes) and grasslands, as well as the particular vegetation of the river Douro banks (Carvalho \& Frazão-Moreira 2011, Gonzalez et al. 2017, ICNF 2020).

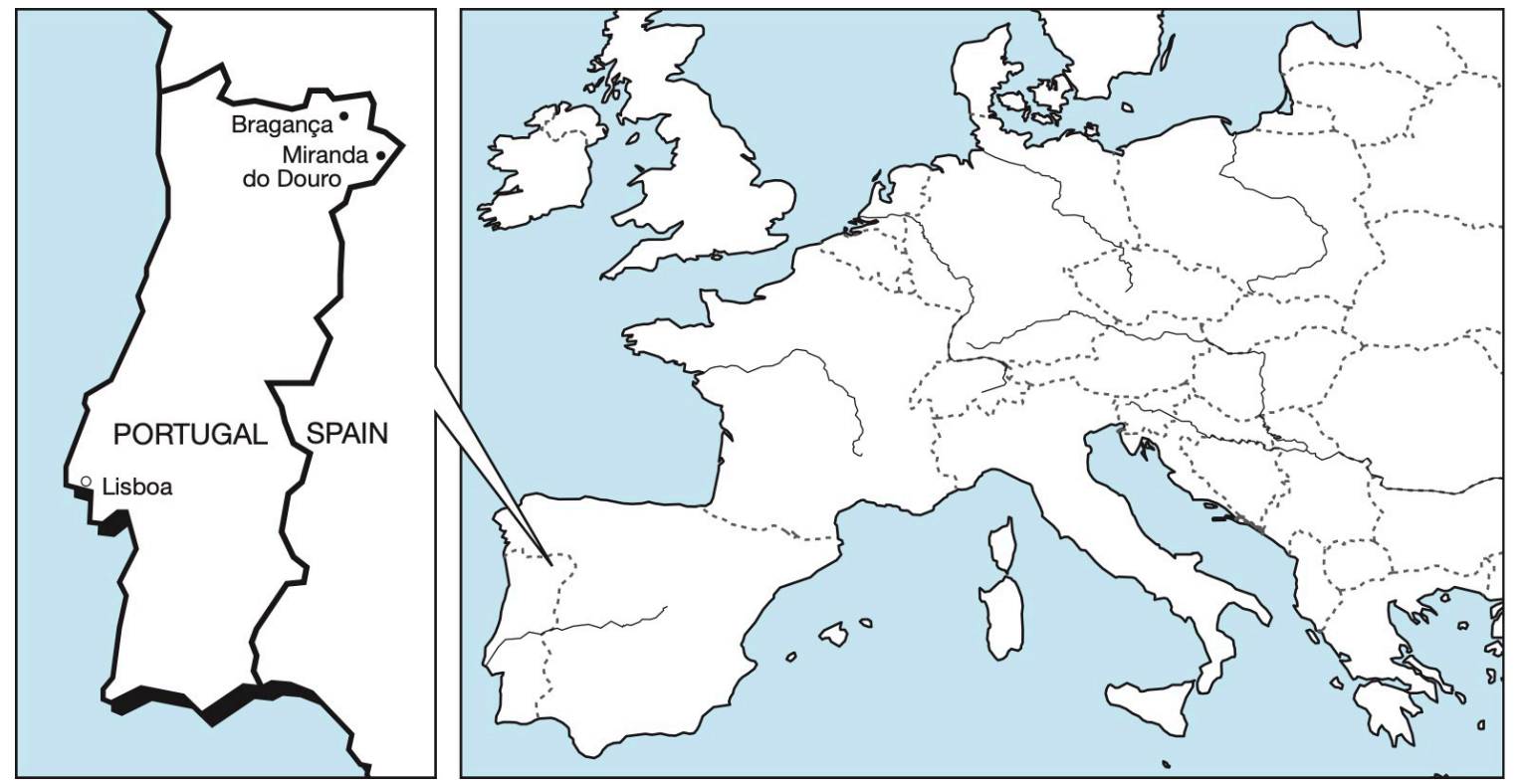

Figure 1. Map showing the two Portuguese study sites: Bragança and Miranda do Douro municipalities from the administrative region of Trás-os-Montes (TM), Northeastern Portugal. 
The first village surveyed, Quintanilha, is in the Spanish border, $20 \mathrm{~km}$ far from the nearby city of Bragança, capital of the district (Figure 1). Residents are predominantly old people who are pensioners or farmers, adults and some younger people who work in shops and services or are studying in Bragança. In the past, the economic pattern was characterized by intense agricultural activity mainly involving family farms (ESAB/PNM 2007, Rodrigues 1998). The village has since aged, become increasingly depopulated and a dormitory of Bragança city.

The second site, Póvoa, is also a small village in the Spanish border near Miranda do Douro, a small town on the banks of the river Douro (Figure 1). It still maintains important agricultural and livestock breeding activities. A significant number of families get their main income from livestock, especially cattle and sheep breeding. Nevertheless, most of its younger inhabitants are employed in the tertiary sector in Miranda do Douro. A rural lifestyle with traditional agricultural activities is consequently maintained in an aging and devitalized geographical area.

Both villages were affected by the socioeconomic impacts of emigration and rural exodus that began in the 1960s (Baptista 1993, Godinho 2006, Rodrigues 1996) and continue until recently. Nowadays, these areas are facing demographic ageing. According to the available statistical data, in 2019 the ageing index (number of elder per 100 young) was about $219 \%$ in Bragança and $389 \%$ in Miranda do Douro (PORDATA 2019). Productive, business and organizational restrictions, such as the decline of traditional agriculture, the negative evolution of commercial activity (Cristóvão et al. 2005), and the closure of public services (e.g., agricultural bureaus, health services and educational institutions), have had an impact on the daily life of its inhabitants (Carvalho \& Frazão-Moreira 2011).

Economic and social changes as well as migratory patterns have induced a certain degree of acculturation in these territories. Plant nomenclature and classification can combine traditional and orally transmitted knowledge with more erudite approaches; local plant information can be mixed with exogenous knowledge especially that learned from the media and books, suggesting adaptive behavior for more global trends and lifestyle changes (Frazão-Moreira et al. 2007, 2009). Nevertheless, traditional patterns of gendered division of labor remained: dwelling space, household tasks and rituals (domestic realm and Catholicism) are activities usually performed by women; forestry, hunting and fishing are male domains (Carvalho 2010, 2016). Concerning the farming system (e.g., agriculture, animal production, wild gathering and landscape management), men and women most often have different roles. Women are gardeners and plant gatherers, skillful in produce storage for food, folk medicine, fuel and textiles and they provide fodder for small animal husbandry. Men usually manage cattle, arable land, permanent crops, woodlands, pastures, and forage crops (Carvalho 2010, 2016, Ribeiro 1997).

\section{Results and Discussion}

\section{Plant nomenclature and classification}

Botanical classifications are based on global similarities and differences between individuals and the evolutionary relationships between organisms (Bonada \& Vallès 2016:291). Folk classifications and nomenclature are quite different as the names of the plants also express their differentiation based on a similarity/difference, however, not in a linear or hierarchical manner, but rather in a multifactorial one, seeking an easy recognition of each plant and a practical association. At least, perceptions, multiple relationships and interconnections are used for naming and classifying. For instance, morphological analogies (e.g. size, shape of leaves, types of fruit), organoleptic (e.g. texture, aroma, color, taste), practical (e.g. utilities, medicinal value, toxicity), and sometimes symbolic or religious issues. Therefore, the relations between the botanical nomenclature and the popular nomenclature are practically nonexistent, and then the coincidences that may exist are clearly exceptional. Often the same scientific botanical specimen might have more than one folk name, including semantic and phonetic variations, or a folk name may refer to different botanical species, even taxonomically distant (Bonada \& Vallès 2016:291).

In every system of ethnobiological nomenclature, the most important linguistic categories are the simple ones, that is to say, those made up of "primary lexemes", corresponding to generic taxa, according to the ethnotaxonomic concept of Berlin et al. (1973). Ethnobiological classifications have also some elements designated by "secondary lexemes", which consist of an attribute added to a basic term (specific taxa in Berlin's model).

In both studied communities (Quintanilla and Póvoa), many plant names refer to a single plant species, e.g. lampaça (butterdock, Rumex obtusifolius L.) and oliveira (olive tree, Olea europaea L.). These "primary lexemes" are simple lexical units but there are also some complex lexical units, such as dentede-leão [meaning lion-teeth] (dandelion, Taraxacum officinale (L.) Weber) and erva-prata, [silver-weed] (nailwort, Paronychia argentea Lam.). However, several plant names are formed from the same word, either through derivation or through the addition of specific attributes, especially when the plants are 
recognized as having morphological similarities, such as aromatic properties.

This is the case of well-known medicinal and aromatic plants that in Póvoa are named using a generic term, which is completed with an attribute reflecting particular characteristics of each botanical species. For instance, size, tomilhinha [little thyme] (Thymus zygis L.) or flower color, tomilho-branco [white thyme] (mastic thyme, Thymus mastichina L.) and tomilho-roxo [purple thyme] (Spanish lavender, Lavandula stoechas L.).

Plants labeled with "secondary lexemes" may have different kinds of attributes and determinants. Some attributes highlight morphological features, particularly the colors of stems, leaves and flowers, as we reported for tomilho-branco and tomilho-roxo above examples.

Other attributes underline the plant's habitat, such as avenca-do-monte [meaning wild spleenwort] (spleenwort, Asplenium billotti F.W. Schultz and A. trichomanes subsp. quadrivalens D.E. Mey.) and avenca-do-jardim [garden-spleenwort] (cultivated Asplenium sp. pl.).

Attributes may also refer to origin, as observed with tutsan, (Hypericum androsaemum L.), which is called hipericão-do-Gerês [Gerês hypericum] as it is original from Gerês (a Portuguese mountainous northwestern area). Due to its well-prized medicinal properties was widespread and brought by traders, travelers and in-migrant workers to be cultivated in $\mathrm{TM}$, the most northeastern region of Portugal.

Finally, another important type of naming attribute in TM is gender. Some plants are labeled with the "secondary lexemes" macho [male] and fêmea [female], which clearly correspond to a gender differentiation. In TM contexts, these gendered attributes seem to have particular meanings, beyond the mere sexual differentiation, based on reproductive characters.

\section{Gender as an operator in plant classification}

Plants are named and differentiated on a gender basis as it is evident in the case of the two villages studied (Table 2 summarized the examples collected). Comparing our results with other examples from different cultural contexts, we found that feminine and masculine terms emerge as determinants in a set of different kinds of naming and classifying attributes and in processes that may be common to various cultures.

Table 2. Gendered ethnobotanical classifications: summary of data collected in Trás-os-Montes (TM), Portugal ${ }^{*}$

\begin{tabular}{|c|c|c|c|c|}
\hline \multirow[t]{2}{*}{ Village } & \multicolumn{3}{|c|}{ Plant names } & \multirow{2}{*}{$\begin{array}{c}\text { Main aspects of gendered } \\
\text { differentiation }\end{array}$} \\
\hline & Local name & Gender & Scientific name & \\
\hline \multicolumn{5}{|c|}{ Gender distinction linguistically marked } \\
\hline \multirow{2}{*}{$\begin{array}{l}\text { Several, } \\
\text { including } \\
\text { Quintanilha } \\
\text { and Póvoa }\end{array}$} & hipericão-fêmea & Female & Hypericum. perforatum L. & cylindrical and smooth stem \\
\hline & hipericão-macho & Male & $\begin{array}{l}\text { Hypericum undulatum } \\
\text { Schousb. ex Willd. }\end{array}$ & winged and grooved stem \\
\hline \multirow[t]{2}{*}{ Póvoa } & freixo-fêmea & Female & \multirow[t]{2}{*}{ Fraxinus angustifolia Vahl } & $\begin{array}{l}\text { pendulous branches, small, } \\
\text { tortuous twigs, knobby bark } \\
\text { and slender leaves }\end{array}$ \\
\hline & freixo-macho & Male & & $\begin{array}{l}\text { erect shoots, smooth bark } \\
\text { and solid trunk }\end{array}$ \\
\hline \multicolumn{5}{|c|}{ Gender distinction not linguistically marked } \\
\hline \multirow[t]{2}{*}{ Póvoa } & escova-amarela & Female & Cytisus scoparius (L.) Link & slender stem \\
\hline & escova-da-estrada & Male & $\begin{array}{l}\text { Cytisus grandiflorus (Brot.) } \\
\text { DC. }\end{array}$ & thick stem \\
\hline \multirow[t]{2}{*}{ Quintanilha } & junça & Female & Cyperus sp. & slender grass-like leaves \\
\hline & junco & Male & Juncus effusus L. & round hardy leaves \\
\hline \multirow[t]{2}{*}{ Quintanilha } & papoila-mansa & Female & Papaver rhoeas L. & domesticated habitat \\
\hline & papoila-brava & Male & Papaver sp. & wild habitat \\
\hline \multirow{2}{*}{$\begin{array}{l}\text { Quintanilha } \\
\text { and Póvoa }\end{array}$} & pedamarro & Female & Quercus faginea Lam. & thin leaves and branches \\
\hline & carvalho-macho & Male & Quercus pyrenaica Willd. & $\begin{array}{l}\text { thick branches and } \\
\text { hardwood trunk }\end{array}$ \\
\hline
\end{tabular}

*Data from Carvalho (2010) and Frazão-Moreira \& Carvalho (2009). 
Gendered plants linked to fertility and productivity concepts

In Póvoa (TM, Portugal), we were told how to describe the difference between two types of freixo, the narrow-leafed ash (Fraxinus angustifolia Vahl), a tree native to central and southern Europe. The socalled freixo-fêmea [female ash] has pendulous branches, small, tortuous twigs, a knobby bark, distinctively slender leaves and carries seasonal samaras (e.g. winged often one-seed indehiscent fruit); the freixo-macho [male ash] has erect shoots and a smooth bark on a solid trunk with little branching and longer, broader leaves and does not present fruits.

The two types are botanically considered the same species. However, in this local context, the word freixo (ash) corresponds to a generic name, which includes two plants, each one locally distinguished by different morphological characters of the leaves/shoots and by their reproductive ability (e.g. capability to produce/exhibit fruits) and renamed accordingly: freixo-fêmea [female ash] and freixomacho [male ash].

This kind of gender differentiation of ash trees also occurs in other lberian rural contexts, such as in Piloña, Asturias, Spain (Pardo-de-Santayana \& SanMiguel 2006), where the masculine word fresno (ash) designates trees with no sign of fruit and darker leaves, and the feminine form fresna (feminine word for ash) indicates fruit-bearing trees with lighter colored leaves.

In both examples, from a single botanical species (Fraxinus angustifolia Vahl) two different plants are recognized and named using empirical characteristics, more or less corresponding to the reproductive characters described in academic biology; ash produces three different types of inflorescences: male, hermaphrodite, or mixed male and hermaphrodite flowers. All types are morphologically monoecious (with male and female reproductive organs in the same tree). However, some of them are functionally dioecious (where one type of flowers is dominant and fertile, and the other is underdeveloped). The fact is that ashes can have both male and female flowers on the same tree, but it is more common to find male trees and female trees, bearing respectively mostly male or female flowers; a tree bearing male flowers one year can produce female flowers the next year and conversely. Only trees with female flowers can produce/exhibit fruits. Thus, some trees behave like male plants and do not bear fruit, while others behave like female plants and do bear fruit. The recognition of two different reproductive features and fruit aptitude of ash trees has also been reported in other villages from TM region (Carvalho 2010), where the leaves are used to prepare medicinal infusions. Traditionally, women drink the beverage prepared with the leaves from female trees (freixo-fêmea) and men use leaves from male trees (freixo-macho) that do not bear fruit, because it is believed that each type of tree has different therapeutic properties specifically adjusted to female or male health conditions.

Similarly, in Peru, the huanarpo (Corynaea crassa Hook. f.) can be female (huanarpo hembra) or male (huanarpo macho). The whole plant is used to treat fertility, sexual potency, and in aphrodisiac mixtures. The huanarpo hembra is used in the preparations given to women, and the huanarpo macho in medicines for men (Bussmann and Sharon 2016, Paniagua-Zambrana and Bussmann 2020). Another study concerning this country states that the name of huanarpo macho might also be given to Jatropha macrantha Müll.-Arg. and huanarpo hembra designates Cnidoscolus peruvianus (Müll.-Arg.) J.F. Macbr. The use of any of these by the opposite sex is thought to have anti-aphrodisiac effect (Malca Garcia et al. 2015).

Among people such as the Bunaq of Timor (Friedberg 1968, 1970, 1990), we find quite comparable classificatory schemes. Several plants are named with the same basic terms and gendered attributes are added to identify fertility and sexual profiles. In the case of the Bunaq, trees plants with small leaves and bearing fruits and tubers with a more delicate skin are pana (female), as opposed to plants whose leaves are bigger or have no fruit, called mone (male).

Other examples can be found in Nepal (Boesi 2007) where the expressions mo (feminine) and pho (masculine) occur in plant names as attributes. They are often related to plant size, to other general features, to the morphology of their organs, and notably to flower size and position. The attribute pho often points out to the biggest plant type or to the one having the biggest flowers, whilst the attribute mo indicates the smallest type or the one having the smallest flowers.

Therefore, the Iberian ash differentiation and Bunaq tree categorization are clear examples of anthropomorphic processes of description by gender based on an analogy between human biology common features and plants (e.g. females conceive, males do not). Furthermore, not only are plants differentiated by gender, but also ethnobotanical uses of the gender-differentiated plants are often markedly distinct, corresponding to gender roles associated with socio-cultural contexts. 
Gendered attributes in plant identification, description and naming

Several plants are identified, described or named using similar anthropomorphic gendered attributes that highlight particular characteristics of their morphology when compared to men's and women's body structure or social behavior.

Within several villages in TM (Carvalho 2010), two wild species in the genus Hypericum are known, respectively, as hipericão-fêmea [female hypericum] (common St. John's-wort, Hypericum perforatum L.) and hipericão-macho [male hypericum] (wavy St. John's-wort, H. undulatum Schousb. ex Willd.). Stem shape is what distinguishes these two species: "female" stems are cylindrical and smooth while the "male" ones are winged and grooved. Female plants are used in medicinal infusions, unlike the male plants, which have no direct medicinal application but rather are used to ward off evil.

Likewise, in Asturias, Spain (Pardo-de-Santayana \& San-Miguel 2006), salgueru-hembra [female willow] (goat willow, Salix caprea L.) and salgueru-machu [male willow] (grey willow, Salix atrocinerea Brot.) refer to two species of willow. The wood of the first species is more malleable, and its branches are used for basket making and other handicrafts; the second has harder wood, which is used for shoes and to make handles for farm tools. The authors attempted to determine the social meaning of this gender attribution in two regions in northern Spain (Asturias and Cantabria) and concluded that although the pattern of gender classification was not always consistent among interlocutors, the female epithet mostly referred to productive, cultivated, large trees with malleable wood, while barren, wild and smaller trees, hard wooden were considered male.

Another example is highlighted by NALU of GuineaBissau (Frazão-Moreira 2001, 2009). This people consider that two tree species in the same scientific genus have the same vernacular name and are distinguished by the lexemes tchill (male) and thai (female): masamp tchill (Albizia dinklagei Harms) and masamp thai (Albizia adianthifolia W. Wghit). In this example, trees are given male attributes and male specific epithets because of the hardness of the wood in contrast to those individuals that have a similar shape but are less tough which are female.

Besides different geographic and cultural contexts, in all these examples, the names of plants clearly express gendered cultural representations: masculinity, associated with physical strength and hardness, and femininity, associated with physical weakness and smoothness. As Taylor noted in his study of the folk classification of the Tobelo people (Moluccas Islands, Indonesia): "Several plant characteristics that emphasize the "strength" of the plant seem generally to be considered properties of 'male' forms (including thorniness, hirsuteness of the leaves, and usefulness in houru 'magic/ medicine,' as well as elongation or pointedness of leaves, redness of the medicinally important growth-point, and uprightness of the stem). Other characteristics seem archetypally 'female' (especially fruit-bearing, also other productive uses as food and twine, roundedness and smoothness of leaves, "whiteness" of (i.e., paleness of the greenish) growth-point, and non-uprightness of the stem) (1990: 29).

Although centered in distinct socio-cultural mores, worldviews and religions, the symbolic differentiation between male and female is essential in the social and political organization of all social contexts mentioned. The definition of gender roles is crucial to the political and economic organization of these societies. The symbolic distinctions of gender are transposed to the classification of plants.

Gendered attributes may also reflect use differences in particular situations as shown in the cases of TM (Portugal), Asturias (Spain), and Peru. Though socially constructed, femininity is made up of both socially defined and biologically created factors.

On the other hand, stereotypes may include the idea that women have a caring nature, so that medicinal, cultivated and large canopy plants are often female, while men are represented as courageous and righteous, with magical, wild, hard, and barren plants often being male.

Such symbolic gender distinctions do not necessarily mean that in different societies, different social practices are so completely dichotomous and rigid. Gender is widely perceived in human societies as a continuum, and social practices do have substantial degrees of flexibility (Pfeiffer \& Butz 2005). However, symbolic oppositions between male and female have metaphorical value (Strathern 1995). Through them, people incorporate certain perceptions of a particular culture, often legitimizing gender-based social inequalities. These oppositions are expressed tightly in plant classifications, in some to a much greater degree than in others.

\section{Gendered plants are not always linguistically marked}

The previous examples involved the anthropomorphic operation made by local people that identifies and explains the differences between plants, based on analogous characteristics or attributes that are used for expressing both human gender differences and morphological or biological plant features. However, gendered representations of plants are not always linguistically evident, which is reflected in Table 2. 
Again, in Póvoa and Quintanilha (TM, Portugal), the carvalho-macho [male oak tree] (Quercus pyrenaica Willd.) with its lobed leaves, thicker branches and hardwood trunk is sometimes distinguished by interlocutors and older inhabitants from the pedamarro (Portuguese oak, Quercus faginea Lam.), which is considered a "female" oak-tree with its thinner leaves and branches.

Elsewhere, a very old Mauritanian man explained how to identify different botanical species of acacias, all of which have similar general morphology:

"Temat (Acacia ehrenbergiana Hayne) is more fragile than talhaia (Acacia tortilis Hayne). Temat trunks are more delicate and break more easily. Talhaia leaves are bigger and not bitter, the trees' roots and trunk are stronger and is more beautiful to look at. There is something big about the talhaia! Looking at both plants is like looking at a man and a woman. One (talhaia) looks like a man and the other (temat) looks like a woman." (Frazão-Moreira personal fieldwork data, 2006)

We saw before that distinction between ash trees (freixos) within the same botanical species was established by naming the two conceptually recognized types of plants (fertile or non-fertile specimens) in certain villages of Portugal and Spain. On the contrary, gender descriptions for oak and acacia trees were not linguistically marked, since there was no consistent or lexical distinction among terms used for naming such plants. In the Portuguese example, the male plant is called carvalho-macho (Quercus pyrenaica) and the female plant pedamarro (Quercus faginea), a completely different name. In the Mauritanian example, two species of acacias are locally known as temat and talhaia, two different words although they are considered similar trees and perceived to belong to the same type of plants.

Gender differentiation, in these cases, was not expressed in "folk taxonomic nomenclature", according with Berlin's term. However, they confirm that how people mentally categorized and classify beings cannot be explained or understood only by means of linguistic analysis. Therefore, naming, identification and classification mechanisms do not always match in cognitive process of plant categorization (Friedberg 1970, 1986, Martin 1975).

Moreover, such examples illustrate the viewpoint defended by Ellen (1993) that in any ethnobiological categorization, there is rarely a direct correspondence (meaning) between category and term because not every word implies separate categories, and the cognitive categories may be defined regardless of lexical labels.
An example of this fact is the nomenclature and categorization of bushes commonly known elsewhere in Portugal as giestas (brooms) but called escovas [brushes] in Póvoa (TM).

Their names, escova-branca [white-brush] (Cytisus multiflorus (L'Hér.) Sweet) and escova-amarela [yellow-brush] (common broom, Cytisus scoparius (L.) Link), point out differences in flower color. A third case of this category is the escova-da-estrada [roadbrush] (Cytisus grandiflorus (Brot.) DC.), whose vernacular name indicates the usual habitat of the species, and its exogenous origin (the former JAE, Autonomous Highway Authority, has cultivated it to stabilize road embankments and adjacent pathways). Escova-da-estrada (Cytisus grandiflorus) has yellow flowers much like the common broom, yet the stems are thicker and rough. These plants are also conferred gender differences in certain situations, as a woman noted while explaining how she picks common broom (escova-amarela) to prepare a medicinal infusion or as she collects seeds to propagate the plant:

"(I pick) the ones that are more-slender, that are female, because they are not so good if they are male (...). The male (road-brush) has a thicker trunk, the female (common broom) is moredelicate and I then go to a bush and see which are the most slender, and I pick the pods."

Another woman from Quintanilha found no better reason to distinguish between papoila-mansa [tamepoppy] (corn-poppy, Papaver rhoeas L.) and papoilabrava [wild-poppy] (Papaver sp.), than to say: "this one is female (corn poppy), oh, the other I dunno, it is from out there in the fields (wild-poppy)". Moreover, pointing to various junça plants (sedges) she made clear that "in plants, it's like among humans, there's male and female! Junça (sedge, Cyperus sp.) is female, junco (common rush, Juncus effusus L.) is male". When we asked for more precise information, we were told that "all plants have males and female specimens; the male ones are out in the fields", which for our interlocutor means wild.

Strictly speaking, no other interlocutors attributed a gender to any of these plants or associated male plants with an undomesticated habitat. Gender differentiation of these species and this wider association are probably not part of local knowledge. What is culturally shared is the attribution of a sexual quality to plants in general, and this possibility was raised in this case, in order to have a chance for replying to researchers in a theoretical and artificial situation.

In another example, reported by Indjai (2017), when two Bijagó (Guinea-Bissau) healers wanted to explain 
to him the differences between two trees of the Apocynaceae family - Rauvolfia vomitoria Afzel and Alstonia bonnei De Wild. - they evoked the metaphor of the genre. One healer called Rauvolfia vomitoria male because it is used for the treatment of male sexual impotence; in reverse, the other healer explained that Rauvolfia vomitoria is female and Alstonia bonnei male, because the latter is much larger than the former.

In brief, attributing gender to plants seems to be a translocal and possibly universal practice. Even though these gendered plants might fit some scientific and botanical categories, such as: 1) a single botanical species; 2) similar species from the same genus; 3) different species from different genera; 4) different parts of plants; 5) different plants of the same species with different growth patterns, which can be caused by many factors.

Therefore, linguistics, i.e. language meaning and language in context, provide resources for appropriate interpretation of habitat, recurrent morphological features or productive characteristics and function of the species. These topics are of great interest and highlight the role of folk classification of botanicals in assessing plant diversity, conservation and management.

However, words used for naming gendered plants, do not always describe or directly represent feminine or masculine attributes, e.g. gendered names for oaktrees in TM and for acacia species in Mauritania, as explained above.

At least, the idea of gender might not be expressed in the name of the plants but can be brought into the distinction of plants in contextual situations, it is clear from local explanations of the different types of brooms in TM, as well as in differences between trees given by Bijagó healers. These examples point to the flexibility and variability of plant classification.

\section{Other dimensions of gendered plant differentiations}

In terms of ethnobotanical classifications, there is no encompassing classification based on gender. Within the given examples, interlocutors did not divide the plant world into the general dichotomous categories of male and female plants. A global division of plants into female and male designations would only be made possible by means of a purely linguistic examination into cases where the local language has noun genders (see Pardo-de-Santayana \& SanMiguel 2006, who tried to analyze the use of feminine and masculine definite and indefinite articles in the naming of fruit trees in Asturias and Castile, Spain).
It subsequently appears that gender distinction is merely evoked, along with other characteristics such as the plant habitat, origin or color, to distinguish morphological units that are often very much alike.

However, the female or male characters of certain species can vary throughout the year according to their phenology (state of development) and function at different moments. For instance, San-Miguel (2007) explains that in Asturias (Spain) espineres or la espinera (both feminine nouns) are the Asturian names for blooming thornbushes (hawthorn, Crataegus monogyna Jacq. and blackthorn, Prunus spinosa L.), in spring. However, in winter these same species are respectively called espinu machu [male thorn] and espinu negru [black thorn], male gender expressions. In this Asturian dialect example, the two wild bushes are mainly recognized as males, being considered female plants only during blossom.

In contrast, the cognitive differentiation of plants by gender can also refer to a practical and economical dimension when it includes labor division and differences in the uses of plants that are considered female or male. In TM (Portugal), growing flax for making linen and for medicinal purposes was a task of skillful women while crops such as wheat and rye cultivated in arable lands were men's responsibility and expertise. Therefore, local people consider that flax is a female plant and women' crop and grains are male ones, belonging to men's domain (Carvalho 2010).

How people refer to useful plants in social practices also shows that men and women differently appropriate some species. For instance, several plants, such as feverfew (Tanacetum parthenium L.), used by women to prepare homemade remedies for genitourinary feminine disorders, are locally viewed as female plants; water dropwort (Oenanthe crocata L.) which men use to prepare bait for fishing is regarded as a male plant (Carvalho 2010).

A study carried out by Sillitoe (2003) shows precisely the relationship between a symbolic organization of the plant world and a social and economic organization of the communities. In Wola society (Papua, New Guinea) there is a gender differentiation of crops based on anthropomorphic concepts of male and female sexuality which are related with the division of labor. Thus, female crops correspond to prostrate plants growing horizontally (e.g. sedge and sweet potatoes) cultivated by women, while male ones are species exhibiting an erect growth form (e.g. bamboo and bananas).

Similar examples can be found in other societies. For instance, in the Kwere and Zigua tribes in Tanzania labor gender specialization is connected with the fact 
that men work on arboriform ligneous plants whereas women mostly collect herbaceous plants (Luoga et al. 2000).

As we have seen, gender as a plant classification operator can be permanently set in the name or in distinctive characters of the plant, but it can also be invoked to express distinctions in contextualized and practical situations, such as productivity and labor.

We tend to accept Sillitoe's thesis (2003), corroborated by Pardo-de-Santayana \& San-Miguel (2006), that plants are placed within social classifications that are related to gender roles. Differences in gender, especially those connected to the reproduction of mores and social organization, become the basis of a cognitive construction of distinctive labels by means of attributing gender to plants. This mechanism seems to be common in every culture.

\section{Gendered differences in male and female} knowledge of plants

Another important issue while studying plant conceptualization is to understand how men and women are related with plants and if there is gendered variation in ethnobotanical knowledge. Differences in plants knowledge of men and women have been observed in different places, in particular through quantitative studies; four examples from different continents - Guimbo et al. (2011), Schunko et al. (2012), Rashid et al. (2018), Voeks (2007) -; for a more global synthesis of ethnobotanical works focused on gender issues, see Howard (2003b, 2006) and Pfeiffer and Butz (2005).

Within the same social framework and specific cultural context (e.g., the two villages in TM, Portugal) and including both female and male respondents, we investigated whether men and women applied different knowledge when they were asked to group plants. Moreover, we analyzed if there were genderbased variation in plant knowledge.

Based on various studies reviewed, Pfeiffer and Butz (2005) discussed gender differentiation at different scales and stressed that "variation in male and female knowledge of biological taxa occurs for a number of reasons, including differential access to natural resources, geographic origin, different harvesting strategies, cultural roles, and genderdifferentiated knowledge transmission" (2005: 248).

Authors such as Atran (1994), Frazão-Moreira (2009) and Hays (1974) observed that men and women share similar knowledge about classification systems; nevertheless, there are gender differences while performing categorization tasks.

Inspired by these findings, we questioned how gender differences are expressed during categorization procedures in a cultural context where this subject has never been studied. To achieve our purpose, we carried out interviews and pile sorting tasks, as explained before.

\section{Plant grouping and local plant knowledge: how} are they gendered?

The analysis of the results given by all the 51 interlocutors (over 40 years old) shows that men and women shared a great deal of knowledge about plants. However, we observed gendered plant use differentiation that is linked to the division of labor, economic strategies, cultural roles, and genderdifferentiated knowledge transmission. There is a clear gender differentiation in the uses of the selected plants, which influence their recognition and grouping, as expressed in the following results (Table 3).

Table 3. Gendered plant use differentiation in free pile sorting (Quintanilha and Póvoa, Trás-os-Montes (TM), Portugal)

\begin{tabular}{l|c|c|c}
\hline Plant & Most Mentioned Plant use & Men & Women \\
\hline Arçã (Lavandula stoechas L.) & fuel & 11 & 4 \\
\hline Arruda (Ruta chalepensis L.) & ritual & 6 & 15 \\
\hline Carqueja (Genista tridentata L.) & medicinal/condiment & 4 & 10 \\
\hline Erva-prata (Paronychia argentea Lam.) & medicinal & 3 & 10 \\
\hline Ervas-lobas (Tuberaria lignosa (Sweet) Samp.) & medicinal & 3 & 7 \\
\hline Escova-amarela (Cytisus scoparius (L.) Link) & fodder & 2 & 8 \\
\hline Espinheiro (Crataegus monogyna Jacq.) & ornamental/ritual & 3 & 16 \\
\hline
\end{tabular}

Gender differences in plants knowledge thus seem to be associated with the division of labor and to male and female working tasks and responsibilities. Subsequently, men, who collect firewood, highlight that arçã is for fuel, and women, whose routine tasks are the preparation of food and meals, as well as feeding animals, highlight that carqueja (Genista tridentata L.) is for seasoning and escova-amarela (Cytisus scoparius (L.) Link) is fodder for sheep.

It seems also meaningful that mainly women recognize the ornamental/ritual qualities of espinheiro (Crataegus monogyna Jacq.) and the ritual quality of arruda (Ruta chalepensis L.). Espinheiro is 
associated with the religious calendar, especially the Marian cult, and its flowers are used to decorate Our Lady's altar during the month of May, which points to women's role in keeping Roman Catholic rituals up to date. The part women play in using plants for ritual purposes also explains why they acknowledge the arruda's magical qualities and why it is planted in pots and gardens as protective amulets and good omens preventing illness and misfortunes inflicted by the evil eye and witches (for the gendered division of labor and rituals in Portuguese rural contexts see e.g. Cabral 1986, Joaquim 1985, Ribeiro 1997).

Another very important point is that men as well as women always mention common medicinal plants, such as cheirosinha (Thymus zygis L.) or fiolho (Foeniculum vulgare Mill.). However, mainly women recognized the therapeutic uses of certain medicinal plants that have been exclusively mentioned by local experts: erva-prata (Paronychia argentea Lam.), which is used in Quintanilha to prepare carminative and digestive herbal teas, and the ervas-lobas (Tuberaria lignosa (Sweet) Samp.), which people in Póvoa claim to have antibacterial properties and whose decoction is used to heal skin injuries and wounds.

\section{Local experts gender variability in plant categorization}

We observed that the plant knowledge and use differences noted between men and women in the two Portuguese villages, systematically analyzed, would make an interesting study in itself. However, the erosion of knowledge and practices and the difficulty in selecting enough people to interview did not allowed a statistical comparison, given that the amount of meaningful data recorded was not adequate.

Nevertheless, it is interesting to understand the classificatory criteria and the uses that local experts, people with recognized knowledge about flora, have highlighted about these plants.

To illustrate the data collection process, the following paragraphs describe how one of these interlocutors accomplished the task.

Woman (66-year-old farmer with $3^{\text {rd }}$ grade primary school education, Quintanilha):

She started by putting together carrasco, carqueja and arçã; then she grouped espinheiro, fiolho, cheirosinha, tremoceiro-bravo and erva-prata; finally, she made a third group with arruda and agrião. She said that she has formed these groups because some are useful for some things and some for others ("I put them together because they're good for this and that"), and she kept telling us what she was thinking. Meanwhile, she explained that nailwort and lupine could not be put together: "Of course I'm not going to put prata together with tremoceiro-bravo, we can put erva-prata together with fiolho to make tea, when I make fiolho tea, I can also mix a little bit of erva-prata with it."

After these remarks, she decided to regroup the plants of the two initial groups resulting in: 1) fiolho, cheirosinha and erva-prata, because they can be mixed for herbal tea; 2) carqueja and arçã, because they are both simultaneously used for herbal tea and food condiment; 3) espinheiro and carrasco because they bear fruits; 4) tremoceiro-bravo, because it is not useful for herbal tea; 5) arruda and agrião, as in the first attempt.

In spite of first putting carrasco and espinheiro in different groups, she reasoned that the two plants should be put together in her second grouping because she considered that while they were not medicinal, they had other uses. She then grouped them together because "the espinheiro is only good for its small balls (haws) to make liquor and this one (carrasco), its acorns are used to feed the animals", suggesting some analogy between both their fruits, perhaps because they are clearly visible unlike those of other species in the list. With the same reasoning, she left tremoceiro-bravo on its own because "you can't make tea with it." When we ask why it wasn't included in a group, she replied that it was on its own because "it's not afraid to be alone". Arruda and agrião continued to make up a group. She said that "agrião can be used to make soup or salad, and arruda is only good to smoke things, to frighten away witches, but now there are no more witches or anything!" When asked why they were grouped together, she quickly replied: "So, not to be alone, the tremoceiro-bravo is on its own, but this one has now found some company."

Finally, she chose to make a third arrangement, which resulted in the following frame: 1) carrasco, carqueja, arçã and espinheiro, because they are from the scrubland; 2) fiolho and erva-prata, both medicinal plants living in the borders of the paths; cheirosinha and agrião because they are edible; 3 ) arruda and tremoceiro-bravo, as they are both wild species and so they can be together.

She has made her task, mainly based on plant-use. Nevertheless, her choice does not mean disregarding other possible criteria such as morphology or habitat.

The example shows that interlocutors are knowledgeable about plants and have plastic skills that enable a continuous rearrangement of the criteria evoked by categorization tasks.

Some ambivalent and uncertain replies about her reasons for grouping together certain plants, are 
similar to those documented in other studies (e.g. Frazão-Moreira 2009), where responses have a cultural basis, particularly among people with no formal schooling and therefore without having undergone any training in doing this kind of artificial task. For instance, "they're not afraid" or "they've found some company now". This interlocutor apparently used this argument to explain plant groups that fall outside the criterion that governed her categorization: plant-use, particularly medicinal and seasoning use.

Table 4 shows the differences between local experts (4 men and 7 women) with regard to their understanding of the selected plants, based on criteria applied in pile sorting task. For example, while analyzing the case of erva-prata (Paronychia argentea) and ervas-lobas (Tuberaria lignosa) women take into consideration their medicinal uses, whereas men think they are of no use at all. Arruda stood out because Póvoa women did not put it in any of the plant groups, thereby conferring special significance to it, perhaps based on the female appropriation of its magic power. In fact, although the magic use of arruda was mentioned during the interviews and observed in the two villages, it was only in Póvoa that we actually had reports about witches and witchery and supernatural issues. It seems that there is a perpetual memory of the reality of these evil creatures, but recognition of their actual presence only makes a mark in the daily existence of the village with a greater rural lifestyle. On the other hand, in the words of the local experts whose interview we used as an example, in Quintanilha (the village where cultural change is more imminent) "now there are no more witches or anything!"

While carrying out the pile sorting task, local experts expressed gender differences mainly in men's criteria for using habitat to characterize plants, and in women' expertise regarding their knowledge of medicinal and ritual plants. Tendency that was observed in the interviewees in general: the criteria used in the categorization were not only differentiated in terms of gender but also of age (Frazão-Moreira and Carvalho 2014).

These results confirm similar findings of previous studies (Carvalho 2010; Carvalho \& Morales 2013; Carvalho, 2016): within Portuguese rural contexts, that is, women and men agree as to the most common uses attributed to plants, but they differ about specific uses, such as in local traditional medicine and in rituals. Thus, while men and women plant knowledge are substantially overlapping, there are also female and male knowledge differences associated with their embodied experiences or "wayfaring" (Ingold 2011).

\section{Conclusions}

The results of this study show that gender is an operator in classification, and male and female names of plants clearly correspond to a gender differentiation and have particular meanings, beyond the mere sexual difference, based on reproductive characters. Gender differentiation might even occurs based on perception and identification of reproductive features (e.g. female plants have fruits; male plants do not bear fruits) but such evidence is understood and described using anthropomorphic analogies and characteristics. Moreover, folk nomenclature for botanical species also uses gendered attributes that highlight particular traits of the plant's morphology, which are similar to those applied to men's and women's body structure or social behavior, emphasizing gendered cultural representations of femininity and masculinity. For example, small, delicate, graceful, smoothness, and light color are considered female plant qualities; bigger, larger, roughness, dark colors are seen as male features.

Examining plant classifications through a gender perspective allows us to understand that in the conceptualization of the natural environment, transcultural mechanisms can occur. Although gender characteristics endorsed to plants may vary, there are recurring features, which explain the coincidence of gendered plant naming in different cultural contexts. This possibly universality "may result not from features built into the human mind genetically, but from the universal situation of human beings reflecting in linguistics terms about their position in the universe, with regard to themselves, to other humans, and to the external environment, itself mainly 'natural', with which they are faced" (Goody 2004: 258).

Considering the reported research, we have also observed there are gender differentiation within plant naming, identification and distinction, reflecting, in a metaphorical process, a sexual division of labor, social practices and cultural representations of female and male. They are components of a social organization that has a contextual reality, and in this sense, the gender of plants should every time be explained through a local perspective.

These results do not really put into question the existence of cognitive mechanisms with universal contours, but rather that an in-depth understanding must always be ethnographic and by no means confined to structural and universalizing interpretations. We can advocate, following Dwyer, for an Ethnoecology that combines a substantive understanding with the certainty that "human engagement with the world, and the persons unfolding through that engagement, are always and necessarily grounded in metaphor, in tropes, in the imagination" (2005: 21). 
Table 4. Local experts' plant criteria used to categorize the species during pile sorting (Quintanilha and Póvoa, Trás-os-Montes (TM), Portugal)

\begin{tabular}{|c|c|c|c|c|c|c|c|c|c|c|c|}
\hline $\begin{array}{l}\text { Plants used } \\
\text { interviews. } \\
\text { Case study } 1 \text { - } \\
\text { Quintanilha }\end{array}$ & $\begin{array}{l}\text { arçã/ romeiro } \\
\text { (Lavandula } \\
\text { stoechas) }\end{array}$ & $\begin{array}{l}\text { agrião } \\
\text { (Rorippa } \\
\text { Nasturtium- } \\
\text { aquaticum) }\end{array}$ & $\begin{array}{l}\text { agrião-real } \\
\text { (Centranthus } \\
\text { calcitrapae) }\end{array}$ & $\begin{array}{l}\text { arruda } \\
\text { (Ruta } \\
\text { chalepensis) }\end{array}$ & $\begin{array}{l}\text { carqueja } \\
\text { (Genista } \\
\text { tridentata) }\end{array}$ & $\begin{array}{l}\text { carrasco } \\
\text { (Quercus } \\
\text { rotundifólia) }\end{array}$ & $\begin{array}{l}\text { cheirosinha } \\
\text { (Thymus } \\
\text { zygis) }\end{array}$ & $\begin{array}{l}\text { espinheiro } \\
\text { (Crataegus } \\
\text { monogyna) }\end{array}$ & $\begin{array}{l}\text { erva-prata } \\
\text { (Paronychia } \\
\text { argentea) }\end{array}$ & $\begin{array}{l}\text { fiolho } \\
\text { (Foeniculum } \\
\text { vulgare) }\end{array}$ & $\begin{array}{l}\text { tremoceiro- } \\
\text { bravo } \\
\text { (Lupinus } \\
\text { angustifolius) }\end{array}$ \\
\hline $\begin{array}{l}\text { Plants used } \\
\text { interviews. } \\
\text { Case study } 2 \text { - } \\
\text { Póvoa }\end{array}$ & $\begin{array}{l}\text { arçã/ romeiro } \\
\text { (Lavandula } \\
\text { stoechas) }\end{array}$ & $\begin{array}{l}\text { norça } \\
\text { (Bryonia } \\
\text { dioica) }\end{array}$ & $\begin{array}{l}\text { mangerico- } \\
\text { do-monte } \\
\text { (Origanum } \\
\text { virens) }\end{array}$ & $\begin{array}{l}\text { arruda } \\
\text { (Ruta } \\
\text { chalepensis) }\end{array}$ & $\begin{array}{l}\text { escova- } \\
\text { amarela } \\
\text { (Cytisus } \\
\text { scoparius) }\end{array}$ & $\begin{array}{l}\text { freixo } \\
\text { (Fraxinus } \\
\text { angustifólia) }\end{array}$ & $\begin{array}{l}\text { tomilho- } \\
\text { branco } \\
\text { (Thymus } \\
\text { mastichina) }\end{array}$ & $\begin{array}{l}\text { espinheiro } \\
\text { (Crataegus } \\
\text { monogyna) }\end{array}$ & $\begin{array}{l}\text { ervas-lobas } \\
\text { (Tuberaria } \\
\text { lignosa) }\end{array}$ & $\begin{array}{l}\text { fiolho } \\
\text { (Foeniculum } \\
\text { vulgare) }\end{array}$ & $\begin{array}{l}\text { grama } \\
\text { (Sedum sp.) }\end{array}$ \\
\hline
\end{tabular}

Póvoa

Local

Plant criteria used by local experts in plant categorization

\begin{tabular}{|c|c|c|c|c|c|c|c|c|c|c|c|}
\hline W (66) & $C \& M$ & $\mathrm{~F}$ & $*$ & $R$ & $C \& M$ & Un & M & Un & M & $M$ & Un \\
\hline W (56) & C & $\mathrm{F}$ & WU & Un & c & $\mathrm{Fu}$ & C & M & M & M & WU \\
\hline W (58) & $\mathrm{H}$ & Mo & Mo & $M$ & $M$ & $\mathrm{H}$ & $\mathrm{H}$ & $M$ & M & $\mathrm{H}$ & M \\
\hline W (51) & $C \& M$ & $\mathrm{~F}$ & $M$ & $R$ & 0 & $M$ & $M$ & 0 & $M$ & $M$ & 0 \\
\hline W (72) & $M$ & $\mathrm{~F}$ & $M$ & $R$ & WU & WU & $M$ & WU & $M$ & M & WU \\
\hline W (56) & $\mathrm{Ff}$ & WU & $M$ & $R \& W U$ & $\mathrm{Ff}$ & WU & $M$ & WU & $M$ & $M$ & 0 \\
\hline W (74) & WU & $\mathrm{F}$ & M & $\mathrm{R}$ & WU & WU & WU & WU & M & WU & WU \\
\hline M (53) & C\&M & $\mathrm{F}$ & WU & WU & C\&M & $\mathrm{Fu}$ & $C \& M$ & WU & WU & M & Wu \\
\hline$M(65)$ & $C \& M$ & $\mathrm{~F}$ & WU & WU & $\mathrm{Fu}$ & $\mathrm{Fu}$ & C\&M & WU & WU & $\mathrm{F}$ & WU \\
\hline$M(71)$ & $\mathrm{H}$ & $\mathrm{H}$ & $\mathrm{H}$ & $\mathrm{H}$ & $\mathrm{H}$ & $\mathrm{H}$ & $\mathrm{H}$ & $\mathrm{H}$ & $\mathrm{H}$ & $\mathrm{H}$ & $\mathrm{H}$ \\
\hline$M(51)$ & Mo & Un & Un & Un & $\mathrm{H}$ & $\mathrm{H}$ & Mo & $\mathrm{H}$ & Un & Un & Un \\
\hline
\end{tabular}

\section{LEGEND:}

Local experts: W - woman; M - man; (66) - 66 years old.

Criteria for plant categorization:

Criteria for plant categorization:

H - Habitat.

Mo - Morphology.

Un - Undefined. 
However, a substantive perspective of the categorization of plants carried out by men and women local experts showed us a gender differentiation and knowledge, linked to their roles and experiences. We can state that knowledge is continuously under construction, assimilated from the past and placed in the texture of present lives, that is to say "storied".

"For the things inhabitant knows are not facts. A fact simply exists. But for inhabitants, things do not so much exist as occur. Lying at the confluence of actions and responses, they are identified not by their intrinsic attributes but by the memories they call up. Things are not classified like facts, or tabulated like data, but narrated like stories" (Ingold 2011: 154).

\section{Declarations}

List of abbreviations: TM: Trás-os-Montes (Northeastern Portuguese region)

Ethics approval and consent to participate: The research team explained to the interlocutors and the local community members the purpose of the study before data collection, and oral consent were obtained (Written informed consent was not required for this study in accordance with the national legislation and the institutional requirements). The study was approved by the institutions involved: CEAS - Centro de Estudos de Antropologia Social, Lisbon, Portugal, and ESA-IPB - Escola Superior Agrária, Instituto Politécnico de Bragança, Bragança, Portugal.

Consent for publication: Not applicable.

Availability of data and materials: The data was not deposited in public repositories. Voucher specimens are kept in the herbarium of the Escola Superior Agrária de Bragança (BRESA). Voucher specimens from Mauritania are kept in the herbarium of CRIA - Centre for Research in Anthropology (LAECRIA) and in the herbarium of IICT - Instituto de Investigação Científica Tropical (LISC). Plant scientific names according to The Plant List (2013), http://www.theplantlist.org/ (verified in January 2019).

Competing interests: The authors do not have any competing interests.

Funding: The data presented were collected in the project "Ethnobotany of the Northeastern Region of Portugal: local knowledge, plants and uses", founded by FCT - Fundação Ciência e Tecnologia, Portugal (References: $\quad$ - POCTI/ANT/48629/2002; POCl/ANT/59395/2004). The Frazão-Moreira personal data from Wadane (Mauritania) were gathered in the micro-project "Arabic gum. From caravans to the local appropriation in Mauritanian oasis modernity", included in "Portuguese castles abroad. Heritage and cultural cooperation between Portugal and Arab-Islamic countries", founded by FCT (Reference: POCTI/ANT/48629/2002; Silva 2013).
Authors' contributions: Amélia Frazão-Moreira and Ana Maria Carvalho designed the study, conducted the fieldwork, did data analysis and wrote the manuscript. Ana Maria Carvalho carried out the botanical identification of plants from Portugal.

\section{Acknowledgements}

We are grateful to the people of Trás-os-Montes (Portugal) communities for participating and sharing with us all their knowledge, enthusiasm and patience. We also thank Elisabete Martins who collaborated in data collection.

\section{References cited}

Alexiades M. 1996. Collecting ethnobotanical data: an introduction to basic concepts and techniques. In Selected Guidelines for Ethnobotanical Research: A Field Manual. Edited by M Alexiades. NYBC, New York, USA, Pp. 52-94.

Atran S. 1986. Fondements de l'Histoire Naturelle. Pour Une Anthropologie de la Science. Complexe, Paris, France.

Atran S. 1994. Core domains versus scientific theories: Evidence from systematics and Itza-Maya folkbiology. In Mapping the mind: Domain specificity in cognition and culture. Edited by L Hirschfeld \& S Gelman. Cambridge University Press, Cambridge, U.K., Pp. 316-340.

Baptista FO. 1993. Agricultura, espaço e sociedade rural. Fora do Texto, Coimbra, Portugal.

Berlin B. 1978. Ethnobiological classification. In Cognition and Categorization. Edited by E Rosch \& B Lloyd. Lawrence Erlbaum Associates, Hillsdale, USA. Pp. 9-26.

Berlin, B. 1992. Ethnobiological Classification Principles of Categorization. Princeton University Press, Princeton, USA.

Berlin B, Bredlove, DE, Raven PH. 1973. General principles of classification and nomenclature in folk biology. American Anthropologist 75(1):214-242.

Bernard HR. 2002. Research Methods in Anthropology. Qualitative and Quantitative Approaches. Altamira Press, Walnut Creek, USA.

Boesi A. 2007. The nature of Tibetan plant nomenclature. The Tibet Journal 33(1):3-28.

Bonada J, Vallès J. 2016. La Nomenclatura botànica i els noms catalans de les plantes. Reflexions a propòsit d'un recull de fitònims. Estudis Romànics 38:283-294.

Bussmann, RW, Sharon, D. 2018. Medicinal plants of the Andes and the Amazon-The magic and medicinal flora of Northern Peru. Ethnobotany Research and Applications 15:1-295. 
Cabral JP. 1989. Filhos de Adão, Filhas de Eva. A visão do mundo camponesa do Alto Minho. Don Quixote, Lisbon, Portugal.

Camou-Guerrero A, Reyes-García V, MartínezRamos M, Casas A. 2008. Knowledge and use value of plant species in a Rarámuri community: a gender perspective for conservation. Human ecology 36(2):259-272.

Cardoso D, de Queiroz L, Bandeira F, Góes-Neto A. 2010. Correlations between indigenous brazilian folk classifications of fungi and their systematics. Journal of Ethnobiology 30(2):252-264.

Carvalho AM. 2010. Plantas y sabiduría popular del Parque Natural de Montesinho. Un estudio etnobotánico en Portugal. Consejo Superior de Investigaciones Científicas, Madrid, Spain.

Carvalho AM. 2016. Homegardens in north-eastern Portugal: former features, roles, gendered knowledge and practice. Gaia Scientia, Special Edition Europe 10 (2):10-25. doi:10.21707/gs.v10.n02a02

Carvalho AM, Frazão-Moreira A. 2011. Importance of local knowledge in plant resources management and conservation in two protected areas from Trás-osMontes, Portugal. Journal of Ethnobiology and Ethnomedicine 7:36. doi: 10.1186/1746-4269-7-36

Carvalho AM, Morales R. 2013. Persistence of Wild Food and Wild Medicinal Plant Knowledge in a NorthEastern Region of Portugal. In Ethnobotany in the New Europe: People, Health and Wild Plant Resources. Edited by M Pardo de Santayana, A. Pieroni \& R Puri. Berghahn Books, Oxford, U.K., Pp. 147-171.

Cristovão A, Tibério M, Cabero-Diéguez V. 2005. Microproduções Agrícolas e Desenvolvimento Local no Douro-Duero. Universidade de Trás-os-Montes e Alto-Douro/Universidade de Salamanca, Vila Real, Portugal.

Dwyer PD. 2005. Ethnoclassification, ethnoecology and the imagination. Le Journal de la Société des Océanistes 120-121:11-25.

Ellen R. 1979. Introductory essay. In Classifications in Their Social Context. Edited by $R$ Ellen \& $D$ Reason. Academic Press, London, U.K., Pp. 1-32.

Ellen R. 1993. The Cultural Relations of Classification. An Analysis of Nuaulu Categories from Central Seram. Cambridge University Press, Cambridge, U.K.

Ellen R. 2006. Introduction. In Ethnobiology and the Science of Humankind. Edited by R Ellen. Blackwell, Malden, USA, Pp.1-21.

ESAB/PNM (Escola Superior Agrária de Bragança/Parque Natural de Montesinho). 2007.
Plano de Ordenamento do Parque Natural de Montesinho. ESAB, Bragança, Portugal.

Frazão-Moreira A. 2001. As Classificações Botânicas Nalu (Guiné-Bissau): Consensos e Variabilidades. Etnográfica 5(1):131-155.

Frazão-Moreira A. 2006. Arabic Gum: From its historical importance in the global markets to its contemporary significance in the local context of Mauritania. In Proceedings. IVth International Congress of Ethnobotany (ICEB 2005). Edited by ZF Ertug. Zero Publications, Istanbul, Turkey, Pp. 545550.

Frazão-Moreira A. 2009. Plantas e Pecadores. Percepções da Natureza em África. Livros Horizonte, Lisbon, Portugal.

Frazão-Moreira A, Carvalho AM. 2009. Etnobotânica do Nordeste Português: Saberes, plantas e usos. Relatório final do Projecto POCI/ANT/59395/2004. Centro em Rede de Investigação em Antropologia (CRIA)/Centro de Investigação de Montanha (CIMO), Lisbon, Portugal.

Frazão-Moreira A, Carvalho AM. 2014. When the young think that every plant is parsley! Social variability of ethnobotanical knowledge and plant categorization in two rural areas in Portugal. In Environmental Special Issue on Anthropology. Edited by C Casanova \& S Frias. Sociedade de Geografia de Lisboa, Lisbon, Portugal, Pp. 58-68.

Frazão-Moreira A, Carvalho AM, Martins ME. 2007. Conocimientos acerca de plantas en la nueva ruralidad. Cambio social y agro ecología en el Parque Natural de Montesinho (Portugal). Perifèria, Revista d'Investigació i Formació en Antropologia de la Universitat Autònoma de Barcelona 7. doi: 10.5565/rev/periferia.173

Frazão-Moreira A, Carvalho AM, Martins ME. 2009. Local ecological knowledge also 'comes from books': Cultural change, landscape transformation and conservation of biodiversity in two protected areas in Portugal. Anthropological Notebooks 15 (1):27-36.

Friedberg C. 1968. Les méthodes d'enquête en ethnobotanique. Journal d'Agriculture Traditionnelle et de Botanique Appliquée 15(7-8):297-334.

Friedberg C. 1970. Analyse de quelques groupements de végétaux comme introduction à l'étude de la classification botanique bunaq. In Échanges et Communications. Mélanges Offerts à Claude Lévi-Strauss. Edited by $\mathrm{J}$ Pouillon \& $\mathrm{P}$ Miranda. Mouton, The Hague, Netherlands, Pp. 1092-1131.

Friedberg C. 1977. La femme et le féminin chez les Bunaq du centre de Timor. Archipel 13:37-52. 
Friedberg C. 1986. Classifications populaires des plantes et modes de connaissance. In L'Ordre et la Diversité du Vivant. Edited by $\mathrm{P}$ Tassy. Fayard, Paris, France, Pp. 21-52.

Friedberg C. 1990. Le Savoir Botanique des Bunaq. Percevoir et Classer dans le Haut Lamaknen (Timor, Indonésie). Muséum National d'Histoire Naturelle, Paris, France.

Garnier P. 1987. Les Herbes, les Arbres, les Peuples. Leurs Noms: Comparasions et Corrélations. Mailone Éditeur, Paris, France.

Godinho P. 2006. O Leito e a Margem. Estratégias familiares de Renovação e Situações Liminares em Seis Aldeias do Alto Trás-os-Montes Raiano. Colibri, Lisbon, Portugal.

Goody J. 2004. Thought, Knowledge, and Universals. In Nature Knowledge. Ethnoscience, Cognition, and Utility. Edited by $G$ Sanga \& $G$ Ortalli. Berghahn Books, New York, USA, Pp. 249-261.

Guimbo ID, Mueller JG, Larwanou M. 2011. Ethnobotanical knowledge of men, women and children in rural Niger: a mixed-methods approach. Ethnobotany Research and Applications 9:235-242. doi: 10.17348/ERA.9.0.235-242

González JA, Carvalho AM, Vallejo JR, Amich F. 2017. Plant-based remedies for wolf bites and rituals against wolves in the Iberian Peninsula: Therapeutic opportunities and cultural values for the conservation of biocultural diversity. Journal of Ethnopharmacology, 209:124-13. doi: 10.1016/j.jep.2017.07.038.

Hays T. 1974. Mauna: Explorations in Ndumba Ethnobotany. Ph.D. Dissertation, University of Washington. University Microfilms International, Ann Arbor, USA.

Heckler S. 2002. Traditional ethnobotanical knowledge loss and gender among the Piaroa. In Ethnobiology and Biocultural Diversity: Proceedings of the Seventh International Congress of Ethnobiology. Edited by JR Stepp, FS Wyndham \& RK Zarger. International Society of Ethnobiology, Athens, USA, Pp. 532-548.

Howard PL. 2003a. Women and plant world: an exploration. In Women \& Plants. Gender Relations in Biodiversity Management and Conservation. Edited by PL Howard. Zed Books, London, U.K., Pp. 1-48.

Howard PL. (Ed.) 2003b. Women \& Plants. Gender Relations in Biodiversity Management and Conservation. Zed Books, London, U.K.

Howard PL. 2006. Gender bias in ethnobotany: propositions and evidence of a distorted science and promises of a brighter future. Distinguished Economic Botanist Lecture 2005. Kew Royal Botanical
Gardens.http://kent.academia.edu/PatriciaHoward/P apers.

ICNF, Instituto de Conservação da Natureza e Florestas. 2020. Áreas protegidas. Parques Naturais. Available at http://www2.icnf.pt/portal/ap/p-nat (accessed January 20, 2020)

Indjai B. 2017. O saber local sobre a utilização das plantas medicinais na Área Marinha Protegida Comunitária das Ilhas Urok (Reserva da Biosfera do Arquipélago Bolama Bijagós, Guiné-Bissau). Master thesis. FCSH - UNL, Lisbon, Portugal.

Ingold T. 2000. The Perception of the Environment: Essays on Livelihood, Dwelling and Skill. Routledge, London, U.K.

Ingold T. 2011. Being alive: Essays on Movement, Knowledge and Description. Routledge, London, U.K.

International Society of Ethnobiology Code of Ethics. 2006. (with 2008 additions). http://ethnobiology.net/code-of-ethics/

Iriarte L, Lazarte L, Franco J, Fernandez D, Eyzaguirr, P. 2000 The role of gender in the conservation, location and management of genetic diversity in potatoes, tarwi and maize in Pocoata, Bolivia. In Participatory approaches to the conservation and use of plant genetic resources. Edited by $\mathrm{E}$ Friis-Hansen, $\mathrm{S}$ Bhuwon, International Plant Genetic Resources Institute, Rome, Italy, Pp. 131139.

Jinxiu W, Hongmao L, Huabin H, Lei G. 2004. Participatory approach for rapid assessment of plant diversity through a folk classification system in a tropical rainforest: case study in Xishuangbanna, China. Conservation Biology 18(4):1139-1142.

Joaquim T. 1985. Mulheres de uma Aldeia. Ulmeiro, Lisbon, Portugal.

Kujawska M, Jiménez-Escobar ND, Nolan JM, AriasMutis D. 2017. Cognition, culture and utility: plant classification by Paraguayan immigrant farmers in Misiones, Argentina. Journal of Ethnobiology and Ethnomedicine, 13:42. doi: 10.1186/s13002-0170169-4

Luoga EJ, Witkowski ETF, Balkwill K. 2000. Differential utilization and ethnobotany of trees in Kitulanghalo Forest Reserve and surrounding communal lands, eastern Tanzania. Economic Botany 54:328-343.

Malca Garcia G, Hennig L, Sieler J, Bussmann RW. 2015. Constituents of Corynaea crassa "Peruvian viagra". Revista Brasileira de Farmacognosia, 25(2):92-97. 
Madden R. 2010. Being Ethnographic: A Guide to the Theory and Practice of Ethnography. Sage, London, U.K.

Martin GJ. 1995. Ethnobotany: a Methods Manual. Chapman and Hall, London, U.K.

Martin MA. 1975. L'ethnobotanique, science per se? A propos d'un livre de B. Berlin, D. E. Breedlove, P. $H$. Raven «The principles of tzeltal plant classification». Journal d'Agriculture Traditionnelle et de Botanique Appliquée 22(7-8):237-276.

Morris B 1984. The pragmatics of folk classification. Journal of Ethnobiology 4(1):45-60.

Newmaster S, Subramanyam R, Ivanoff R, Balasubramaniam N. 2006. Mechanisms of ethnobiological classifications. Ethnobotany 18:4-26.

Paniagua-Zambrana NY, Bussmann RW. 2020. Corynaea crassa Hook. f. In Ethnobotany of the Andes. Edited by $\mathrm{N}$ Paniagua-Zambrana \& RW Bussmann. Springer Nature Switzerland, Cham, Switzerland, Pp. 619-622.

Pardo-de-Santayana M, San-Miguel E. 2006. The gender of plants according to popular nomenclature in the North of Spain. In Proceedings of IVth International Congress of Ethnobotany. Edited by ZF Ertug. Zero Publications, Istanbul, Turkey, Pp. 461466.

Pfeiffer J, Uril Y. 2003. The role of indigenous parataxonomists in botanical inventory: from Herbarium Amboinense to Herbarium Floresense. Telopea 10(1): 61-72.

Pfeiffer JM, Butz RJ. 2005. Assessing Cultural and Ecological Variation in Ethnobiological Research: The Importance of Gender. Journal of Ethnobiology 25(2):240-278.

PORDATA. 2019. Base de Dados de Portugal Contemporâneo - Índice de envelhecimento por Município. Fundação Francisco Manuel dos Santos. https://www.pordata.pt/Municipios/\%C3\%8Dndice+d e+envelhecimento-458 (accessed January 20, 2020).

Price L (2006). Wild food plants in farming environments with special reference to Northeast Thailand, food as functional and medicinal, and the social roles of women. In Eating and Healing: Traditional food as medicine. Edited by A Pieroni \& $L$ Price. Food Products Press, New York, USA, Pp.6599.

Ragupathy S, Newmaster B, Murugesan M, Velusamy B. 2009. DNA barcoding discriminates a new cryptic grass species revealed in an ethnobotany study by the hill tribes of the Western Ghats in southern India. Molecular Ecological Resources 9:172-180.
Rashid N, Gbedomon RC, Ahmad M, Salako VK, Zafar M, Malik K. 2018. Traditional knowledge on herbal drinks among indigenous communities in Azad Jammu and Kashmir, Pakistan. Journal of Ethnobiology and Ethnomedicine 14(1):16. doi: 10.1186/s13002-018-0217-8

Ribeiro M. 1997. Estratégias de reprodução socioeconómica das unidades familiares camponesas, em regiões de montanha. Fundação Calouste Gulbenkian, Lisbon, Portugal.

Rodrigues O. 1996. A mudança do espaço rural em zonas marginais: o caso da Terra Fria Transmontana. In O Voo do Arado. Edited by J Brito, F Baptista \& B Pereira. Museu Nacional de Etnologia, Lisbon, Portugal, Pp. 385-395.

Rodrigues O. 1998. A terra e a mudança. Reprodução social e património fundiário na Terra Fria Transmontana. Instituto Politécnico de Bragança, Bragança, Portugal.

Ross N. 2002. Cognitive aspects of intergenerational change: mental models, cultural change, and environmental behavior among the Lacandon Maya of Southern Mexico. Human Organization 61(2):240278.

San-Miguel E. 2007. Tengo de subir al árbol. Etnobotánica del concejo de Piloña (Asturias). Red de Museos Etnográficos de Astúrias, Gijón, Spain.

Schunko C, Grasser S, Vogl CR. 2012. Intracultural variation of knowledge about wild plant uses in the Biosphere Reserve Grosses Walsertal (Austria). Journal of Ethnobiology and Ethnomedicine 8(1):23. doi: 10.1186/1746-4269-8-23.

Sillitoe P. 2002. Contested Knowledge, Contested Classifications: Animals in the Highlands of Papua New Guinea. American Anthropologist 104(4):11621171.

Sillitoe P. 2003. The gender of crops in the Papua New Guinea highlands. In Women \& Plants. Gender relations in biodiversity management and conservation. Edited by PL Howard. Zed Books, London, U.K, Pp. 165-180.

Sillitoe P. 2006. Ethnobiology and applied anthropology: rapprochement of the academic with the practical. In Ethnobiology and the Science of Humankind. Edited by R Ellen. Blackwell, Malden, USA, Pp.147-175.

Silva MC (Ed.). 2013. Castelos a Bombordo. Etnografias de patrimónios africanos e memórias portuguesas. CRIA - Centro de Investigação em Antropologia, Lisbon, Portugal.

Somnasang P, Moreno-Black G. 2000. Knowing, gathering and eating: knowledge and attitudes about 
wild food in an Isan village in Northeastern Thailand. Journal of Ethnobiology 20:197-216.

Strathern M. 1995. No nature, no culture: the Hagen case. In Nature, Culture and Gender. Edited by $\mathrm{C}$ MacCormack \& M Strathern. Cambridge University Press, Cambridge, U.K., Pp. 174-222.

Tamisari F, Bradley J. 2003. To have and to give the law: Animal names, place and event. In Animal names. Edited by A Minelli, G Ortalli \& G Sanga. Istituto Veneto di Scienze Lettere ed Arti, Venice, Italy, Pp. 419-438.

Taylor, PM. 1990. Folk Biology of the Tobelo People: A Study in FolkClassification. Smithsonian Institution Press, Washington, USA.

Torres-Avilez W, Medeiros P, Albuquerque, UP. 2016. Effect of gender on the knowledge of medicinal plants: systematic review and meta-analysis. Evidence-Based Complementary and Alternative Medicine 2016.

Voeks RA. 2007. Are women reservoirs of traditional plant knowledge? Gender, ethnobotany and globalization in northeast Brazil. Singapore Journal of Tropical Geography 28(1):7-20.

Zent S. 2000. Acculturation and Ethnobotanical Knowledge Loss among the Piaroa of Venezuela: Demonstration of a Quantitative Method for the Empirical Study of TEK Change. In On Biocultural Diversity: Linking Language, Knowledge, and the Environment. Edited by L Maffi. Smithonian Institution Press, Washington, USA, Pp. 190-211. 